\title{
The hand that feeds
}

\section{The efficiency of research agencies and their responsiveness to grant applicants vary widely around the world. It is time for the laggards to reform.}

Tror he integrity of the grant-selection process should be the central objective of every research agency - and scientists who apply for grants fully understand that the process must be thorough and exhaustive.

Nonetheless, as we report in this issue (see page 308), grant applicants confront an array of service quality ranging from first-rate to abysmal. Like other consumers of government services, they are entitled to expect a satisfactory level of service from the agencies that they deal with - including politeness from staff, timely responses to enquiries, and ready access to all non-confidential information pertaining to the grant review process.

Instead, some researchers report interminable paperwork, unexplained delays, arbitrary rules and regulations, and ultimate bafflement regarding the actual nature of the review process. Some of this is probably sour grapes from failed grant applicants. And grumpy researchers should bear in mind that the agency's overriding obligation is to the taxpayer whose money it dispenses. Nonetheless, many researchers' complaints are justified, and reflect a level of public-sector incompetence that must be urgently addressed by the agencies in question.

Most of these agencies argue, with varying degrees of persuasiveness, that they are working to improve things. But pinning down their progress can be difficult. Some agencies are tracking their performances against indicators such as the amount of time taken to acknowledge correspondence or to reach decisions. But these criteria - and agencies' performances against them - are often hard for grantees or other taxpayers to track down. And if no one knows the benchmarks, it is hard for anyone to be held accountable.

Some of funders' most useful innovations have been borrowed from the private sector, such as the use of surveys and focus groups to get feedback from grantees. But the analogy with private industry cannot be pushed too far. Research agencies are public bodies with public responsibilities. On the other hand, they face no real competition: researchers can't choose between funders in the same way that consumers can between suppliers.

Pressure on the public sector to improve its performance can move research agencies in the right direction. In Japan, for example, the government of Prime Minister Junichiro Koizumi has pushed for greater transparency and efficiency from its research agencies. In the United States, the Bush administration has asked federal agencies to streamline their submission systems (www.grants.gov), a move that could help the best practices of the strongest research agencies, the National Science Foundation and the National Institutes of Health, to rub off on the rest of government.

But other political pressures can cause bureaucratic demands to stack up. Concerns over the treatment of minorities and women, for example, or over financial conflicts of interest, often lead to additional requirements on grant application forms - which are always easier to add than to remove. Agencies need to look at their forms over time, to see if they still make sense. Researchers, for their part, should bear in mind that the forms may reflect legal requirements over which the agency has no control, as well as priorities, such as fair treatment of applicants, that the researchers probably share.

It is particularly important that agency staff have time to get out and meet the communities they serve: direct contact with these staff is particularly valuable for young scientists who are new to the application process. And discussions with researchers suggest that their level of satisfaction with agencies can be improved through relatively simple steps, such as responding quickly to complaints and maintaining a telephone helpdesk that is manned by real people.

\section{Global reach}

\section{Nations need a more effective way to coordinate their responses to environmental challenges.}

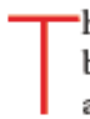
he United Nations Environmental Programme (UNEP) will be looking for a new director-general at the end of this year, and the UN World Summit this week may consider steps to widen the body's influence.

UNEP's departing director, former German environment minister Klaus Töpfer, has worked hard during his eight years in office to strengthen the body's ties with industry, and to get its work taken seriously beyond the narrow circle of environmental groups that have supported its efforts in the past.
But a great deal more needs to be done if this relatively obscure office, with about 450 professional staff and an annual budget of US $\$ 60$ million, is to make any real impact on epic global environmental problems such as global warming, clean air, clean water and biodiversity conservation.

UNEP was set up in 1972 with a mission "to provide leadership and encourage partnership in caring for the environment by inspiring, informing, and enabling nations and peoples to improve their quality of life without compromising that of future generations".

The programme has scored some notable successes on Töpfer's watch, helping to coordinate international discussions on watersupply issues, for example, and helping poor countries develop laws and regulations on complex issues such as the transportation of biological specimens and transgenic plants.

But UNEP is not currently constituted to provide genuine leader- 